ACTA UNIVERSITATIS LODZIENSIS

FOLIA LITTERARIA POLONICA 1(39) 2017

http://dx.doi.org/10.18778/1505-9057.39.09

Kinga Sygizman*

\title{
O narracyjności reportażu radiowego
}

\section{Narracja interdysyplinarna, narracja dźwiękowa}

Istnieje niezliczona ilość opowiadań [recits] na świecie - rozpoczyna rozważania o strukturze narracji ${ }^{1}$ Roland Barthes. - Jest to przede wszystkim cudowna różnorodność gatunków obecnych w najrozmaitszych tworzywach, jak gdyby każde tworzywo skłaniało się ku człowiekowi, by mu powtarzać opowieści²

Opowiadanie więc konstytuuje się w języku pisanym, w systemie znaków ikonicznych, $\mathrm{w}$ gestykulacji, ale także w języku mówionym ${ }^{3}$, w tekście audialnym, a więc $\mathrm{w}$ reportażu dźwiękowym ${ }^{4}$. Opowiadanie, snucie narracji jest właściwe wszystkim epokom, wszelkim wspólnotom, klasom społecznych, kulturom, narodowościom itp. Czy więc uniwersalność opowiadania, jego wszechobecność i popularność uprawniają nas do twierdzenia o jego niewielkiej wartości znaczeniowej? - pyta retorycznie Barthes ${ }^{5}$. Skąd taka powszechność i potrzeba człowieka do snucia narracji? Odpowiedzi na te pytania odnajdujemy w publikacjach Jerzego Trzebińskiego, który podkreśla, że narracyjność leży u podstaw odbierania rzeczywistości, jej interpretowania, rozumienia - nasza wiedza o świecie ma charakter narracyjny

* Dr, e-mail: kinga.klimczak@gmail.com; Uniwersytet Łódzki, Wydział Filologiczny, Katedra Dziennikarstwa i Komunikacji Społecznej; 90-236 Łódź, ul. Pomorska 171/173.

${ }^{1}$ Terminów „narracja” i „opowiadanie” będę w teście używać wymiennie, zgodnie z definicją Stownika języka polskiego, t. 2, red. H. Szkiłądź i in., Państwowe Wydawnictwo Naukowe, Warszawa 1979, a także częstym użyciem tych terminów alternatywnie, o czym pisze choćby M. Głowiński - zob. M. Głowiński, Wokół narratologii, [w:] Narratologia, red. M. Głowiński, Wydawnictwo Słowo/Obraz Terytoria, Gdańsk 2004, s. 5.

${ }^{2}$ R. Barthes, Wstęp do analizy strukturalnej opowiadań, przekł. W. Błońska, „Pamiętnik Literacki" 1986, z. 4, s. 327.

${ }^{3}$ Tamże.

${ }^{4} \mathrm{Na}$ potrzeby tekstu będę używać wymiennie terminów „reportaż” i „dokument radiowy”.

${ }^{5}$ Zob. R. Barthes, dz. cyt., s. 327.

${ }^{6}$ Zob. J. Trzebiński, Wstęp, [w:] Narracja jako sposób rozumienia świata, red. J. Trzebiński, Gdańskie Wydawnictwo Psychologiczne, Sopot 2001, s. 13. 
„Naturalność formy opowiadania, jako środka wyrażania myśli i przeżyć, nie wynika z natury samego procesu komunikowania, lecz jest efektem narracyjnego sposobu pojmowania świata, który z kolei wynika z narracyjnej struktury ludzkiej wiedzy o sobie"7 - pisze Trzebiński. Ponadto forma opowiadania jest ,wygodną i dobrze wyuczoną konwencją" informowania innych o naszych przeżyciach ${ }^{8}$. W podobnym tonie wypowiada się Dorota Filar. Badaczka podkreśla fakt, że struktury narracyjne są ważnym elementem każdej kultury, formami wyrażania uczuć jednostki i danej społeczności. Filar zwraca także uwagę, podobnie jak Barthes, na wielorakość form narracyjnej ekspresji, ustnych, pisanych, wizualnych ${ }^{9}$.

Uniwersalność narracji obserwować możemy w badaniach naukowych, a konkretnie w niesłabnącym zainteresowaniu przedstawicieli różnych nauk problematyką opowiadania i jego funkcjami w życiu człowieka. Narracja, termin niegdyś utożsamiany z rozważaniami teoretyczno-literackimi, dziś przenika do innych dyscyplin, takich jak filozofia, historiozofia, nauki społeczne, psychologia. Infiltracja ta jest - zdaniem Głowińskiego - wielkim, być może jedynym w swoim rodzaju sukcesem nauki o literaturze ${ }^{10}$. Narracja stała się obecnie przedmiotem badań interdyscyplinarnych ${ }^{11}$. Nauki filozoficzne łączą problem narracyjności z doświadczeniem podmiotowości jednostki i kształtowania własnej tożsamości podczas procesu opowiadania. Historiozofowie poszukują „wielkich” narracji, mających znaczenie dla dziejów społeczności, ale także stanowiących zbiór wartości dla pojedynczego człowieka, członka danej wspólnoty $^{12}$. W naukach społecznych narracja rozumiana jest jako intencjonalna wypowiedź, tekst o czymś, wyrażany przez kogoś, powszechnie zaś uznawana jest za sposób komunikowania się ${ }^{13}$. Psychologowie narracyjni akcentują głównie poznawczy i egzystencjalny aspekt narracji - jako narzędzia postrzegania i rozumienia rzeczywistości ${ }^{14}$.

Postacią, której pogląd badawczy stanowi swoistego rodzaju pomost między teorią literatury a psychologią narracyjną, jest Paul Ricouer, autor koncepcji tożsa-

7 Tamże, s. 17.

${ }^{8}$ J. Trzebiński, Problematyka narracji we współczesnej psychologii, [w:] Narracja. Teoria i praktyka, red. B. Janusz, K. Gdowska, B. de Barbaro, Wydawnictwo Uniwersytetu Jagiellońskiego, Kraków 2008, s. 14.

${ }^{9}$ D. Filar, Narracyjność $w$ badaniach interdyscyplinarnych a kategorie narracyjne $w$ semantyce, [w:] Narracyjność języka i kultury, red. D. Filar, Wydawnictwo Uniwersytetu Marii Curie-Skłodowskiej, Lublin 2014, s. 14.

10 M. Głowiński, dz. cyt., s. 6.

${ }^{11}$ Zob. D. Filar, dz. cyt., s. 14.

12 Zob. tamże, s. 19-20.

13 Zob. M. Straś-Romanowska, Psychologia wobec matych i wielkich narracji, [w:] Psychologia małych $i$ wielkich narracji, red. M. Straś-Romanowska, B. Bartosz, M. Żurko, Eneteia. Wydawnictwo Psychologii i Kultury, Warszawa 2010, s. 21.

${ }^{14}$ D. Filar, dz. cyt., s. 20. 
mości narracyjnej. Zdaniem przedstawiciela hermeneutyki sens istnienia i życiowych doświadczeń nigdy nie jest człowiekowi dany z góry, jego odkrycie wiąże się z koniecznością autorefleksji nad tymi doświadczeniami - jak zauważa Filar ${ }^{15}$ - refleksja z kolei możliwa jest $\mathrm{w}$ procesie opowiadania. Człowiek jest zwierzęciem nie tylko rozumnym - homo cogitans - ale też opowiadającym - homo narrans - dlatego autonarracja - jako uniwersalny sposób werbalizowania przeżyć - stanowi konieczny warunek w procesie budowaniu własnej tożsamości ${ }^{16}$. „Zrozumieć samego siebie to być zdolnym do opowiadania o samym sobie historii zrozumiałych i zarazem możliwych do przyjęcia przez innych [...]"17 - pisze Ricoeur. Tym, co nas konstytuuje, jest narracyjna tożsamość, która stwarza się podczas komponowania dynamicznej opowieści, charakteryzującej się zmiennością w czasie ${ }^{18}$. Myślenie narracyjne - w przeciwieństwie do abstrakcyjnego myślenia paradygmatycznego - jest wszak osadzone w zmienności, subiektywizmie i konkrecie ${ }^{19}$.

Psychologiczno-filozoficzna teoria tożsamości [auto]narracyjnej, ukazująca opowiadanie jako narzędzie w procesie poznawania świata i odkrywania własnej tożsamości znajduje swoje odzwierciedlenie w badaniach nad dokumentem dźwiękowym. Radiowi twórcy podkreślają wielokrotnie, że spotkanie reportażysty z bohaterem, możliwość podzielenia się [przez tego drugiego] często traumatycznymi doświadczeniami, zwerbalizowania ich, nazwania własnych uczuć jest swoistego rodzaju terapią. Autorefleksja nad wydarzeniami, o których nie mieli odwagi opowiedzieć nikomu wcześniej, jest elementem dopełniającym ich tożsamość, ale także wyzwalającą spowiedzią.

Uzyskują [zwierzający się $]^{20}$ przez to [autonarrrację], po pierwsze, zdystansowanie się wobec $[\ldots]$ zgryzot $\mathrm{i}$ - do pewnego stopnia - oczyszczenie z nich, a po drugie przekroczenie własnej odrębności i poczucie zjednoczenia z mądrym, dobrym i sprawiedliwym, żywym transcendentnym $e g o^{21}$.

Nic więc dziwnego, że po rozmowie z bohaterem audycji Snajper Louis autorka reportażu, Alicja Grembowicz, usłyszła od niego słowo „dziękuję”.

15 Tamże, s. 18.

${ }^{16}$ Zob. Teorie literatury XX wieku. Podręcznik, red. A. Burzyńska, M.P. Markowski, Społeczny Instytut Wydawniczy Znak, Kraków 2007, s. 185.

${ }^{17}$ P. Ricoeur, Filozofia osoby, przekł. M. Frankiewicz, Wydawnictwo Naukowe Papieskiej Akademii Teologicznej w Krakowie, Kraków 1992, s. 58.

${ }^{18}$ Zob. A. Burzyńska, Idee narracyjności w humanistyce, [w:] Narracja. Teoria..., s. 32.

${ }^{19}$ Zob. D. Czyżowska, Dylematy moralne osób dorostych $i$ sposoby ich rozwiazywania, [w:] Psychologia matych..., s. 41.

${ }^{20}$ Wtrącenia autorki tekstu.

${ }^{21}$ W. Pawluczuk, Zwierzenie, gawędzenie, zgryzota, [w:] Antropologia stowa. Zagadnienia $i$ wybór tekstów, red. G. Godlewski, Wydawnictwo Uniwersytetu Warszawskiego, Warszawa 2003, s. 181. 
„Bo wiesz, ja teraz czuje się wolny, to było dla mnie jak psychoterapia [...]” - powiedział Louis Jurkowlaniec i dodał: „ty mnie słuchałaś [...] i ty mnie nie oceniałaś" "22. Ta umiejętność słuchania bez oceniania leży u postaw dialogu reportażysty z bohaterem dialogu, który często odbywa się bez użycia przez tego pierwszego środków werbalnych, a tylko przy akceptacyjnym skinaniu przezeń głowy i uważnym spojrzeniu. Baczne słuchanie jest - jak zauważają filozofiowie dialogu - istotnym elementem w procesie poznania człowieka ${ }^{23}$. „Aby poznać, czy to jabłoń, czy wierzba, wystarczy znaleźć się w odpowiedniej odległości od drzewa” - zauważa Józef Tischner - ,aby poznać drugiego, samo zbliżenie nie wystarczy. Trzeba, by bliźni sam zechciał się otworzyć przed nami" 24 . Otwieranie rozmówcy, stwarzanie dogodnych warunków do spotkania, a tym samym snucia przez niego narracji, jest wielką umiejętnością twórców dzieł audialnych $^{25}$. Jak zauważa Bengt Bok,

schodzenie w głąb osobowości człowieka jest procesem rozszyfrowywania jego myśli. Dlatego reportażysta musi być wyposażony w zdolność empatii względem Drugiego, powienien potrafić zidentyfikować się z bohaterem, pamiętając cały czas, że opowieść, którą słyszy, nie należy do niego samego, ale jest własnością Drugiego ${ }^{26}$.

Zwierzenie się ze zgryzoty, radości czy sekretu, potrzeba „umieszczenia” tych uczuć w Innym, nie jest możliwa w akcie mowy, ale w związku sympatii lub miłości ${ }^{27}$.

${ }^{22}$ Tym doświadczeniem podzieliła się Alicja Grembowicz podczas Forum Reportażu [to organizowane przy współpracy PR Łódź i Śródmiejskiego Forum Kultury w Łodzi cykliczne spotkania reportażystów z całej Polski z łódzką publicznością. Grembowicz gościła na forum 29 stycznia 2008 r.].

${ }^{23}$ Zob. J.A. Kłoczowski OP, Filozofia dialogu, Wydawnictwo Polskiej Prowincji Dominikanów „W drodze”, Poznań 2005, s. 79.

${ }^{24}$ J. Tischner, Myślenie wedtug wartości, Społeczny Instytut Wydawniczy Znak, Kraków 2005, s. 295.

${ }^{25}$ Zob. Wykład Katarzy Michalak pt. Od pierwszego wejrzenia czyli moje sposoby przeprowadzania wywiadów wygłoszony podczas Seminarium Reportażu poświęconego prezentacji i dyskusji warsztatowej nad radiowym dokumentem artystycznym, Kazimierz Dolny, dn. 22.10.2007 [zarejestrowany wykład w posiadaniu autorki tekstu]. Zob. też: B. Bok, Encounter with the Other. Some reflections on interviewing, Stockholm Academy of Dramatic Arts, Stockholm 2014.

${ }^{26}$ B. Bock, dz. cyt., s. 3-4. W oryginale: „Reaching deep down inside person is a process [...] It's about deciphering a person's thoughts [...] The interviewer must be equipped with a certain capacity for empathy with «the Other». To be able to identify with the Other experiences and at the same time remain strong enough to understand that those experiences are not one's own, but those of the Other". Tłumaczenie autorki tekstu.

${ }^{27}$ Zob. W. Pawluczuk, dz. cyt., s. 176-177. 


\section{Małe i wielkie narracje}

Dla rozważań o narracyjności tekstów audialnych ważnym punktem odniesienia jest psychologia narracyjna. Zwraca ona uwage na poznawcze funkcje narracji, na specyficzną, właściwą człowiekowi umiejętność ujmowania własnych przeżyć w struktury opowiadania, a dalej ich interpretowania. Jak zauważa Straś-Romanowska,

narracyjne konstruowanie i rekonstruowanie rzeczywistości [...] stanowi przejaw naturalnej skłonności interpretacyjnej czlowieka, rozwijającej się w ciągu całego życia pod wpływem kontaktu z wzorcami narracyjnymi obecnymi w kulturze, w dyskursie społecznym i codziennej praktyce językowej $[\ldots]^{28}$.

Jesteśmy wszak istotami interpretującymi i „nadajemy znaczenie wszelkim swoim doświadczeniom, percepcjom [...], opowiadając o nich historie" 29 . Cechą otaczających człowieka zjawisk, a także przeżyć jest dynamika, zmienność, płynność. Przedmioty, ludzie, a zarazem emocje istnieją w relacji do innych przedmiotów, ludzi i uczuć, ich istnienie i interpretacja uwikłane są w przeróżne sytuacyjne konteksty. Żyjący w tej zmienności człowiek stara się ją uporządkować, a środkiem, który to umożliwia, jest właśnie narracja ${ }^{30}$, ponieważ „pomaga [ona] lepiej rozumieć to, co dzieje się w otaczającym świecie, przeżycia innych ludzi, ich sposoby myślenia i motywacje"31. Warunkiem zrozumienia zjawisk jest ich usystematyzowanie i zinterpretowanie, a to z kolei możliwe jest jedynie w toku snucia opowieści. I właśnie owa umiejętność tworzenia osobistej narracji i refleksji jest przedmiotem badań psychologii narracyjnej. Ale nie tylko ona. Badacze takich opowieści przyglądają się także formom ich tworzenia, bowiem każda narracja zbudowana jest w oparciu o takie, a nie inne środki retoryczne, wypowiedziana jest danym tonem przy użyciu konkretnych struktur językowych itd. Wszystkie te elementy składają się na psychologiczny obraz osoby opowiadającej, ujawniają jej dojrzałość, emocjonalność, stan psychiczny, są ,projekcją stanu ducha [świadomości] osoby, subiektywnym obrazem doświadczeń życiowych, dominujących uczuć, pragnień i obaw [...]"32.

Już przyglądając się zakresowi badawczemu psychologii narracyjnej, można z łatwością usankcjonować tezę o jej bliskości z badaniami nad dokumentem radiowym. U podstaw badawczych psychologów i naukowców zajmujących się

\footnotetext{
${ }^{28}$ M. Straś-Romanowska, dz. cyt., s. 22.

${ }^{29}$ B. Janusz, K. Gdowska, B. de Barbaro, Praktykowanie narracji, [w:] Narracja. Teoria..., s. 7.

${ }^{30}$ Zob. M. Straś-Romanowska, dz. cyt., s. 23.

${ }^{31}$ Tamże, s. 24.

32 Tamże, s. 22.
} 
reportażem audialnym leży indywidualna opowieść człowieka, który poprzez tę opowieść porządkuje i interpretuje świat, ale także wyraża swój stosunek do zjawisk, ludzi czy emocji, o których opowiada. Dla przedstawicieli obydwu dziedzin nauki istotna jest nie tylko treść tej narracji, ale także forma, a więc zespół środków językowych użytych do wyrażenia danej treści. W przypadku przekazu audialnego szczególny nacisk kładzie się na warstwę prozodyczną przekazu - barwa głosu, jego tembr, rozłożenie akcentów, intonowanie konkretnych słów / zdań - wszystko to znaczy, zarówno dla psychologa, jak i medioznawcy, choć każdy z nich będzie interpretował te elementy w nieco inny sposób, odpowiedni dla reprezentowanej przez siebie nauki.

Personalne opowieści, mające biograficzny charakter, odnoszące się do osobistych doświadczeń, wyrażające własne przeżycia to tzw. małe narracje. Mają one „,indywidualny wymiar i osobiste znaczenie"33 dla mówiącego. Są jednostkowym sposobem uporządkowania zjawisk bliskich mówiącemu, a tym samym - poprzez możliwość wyrażenia własnego oglądu zdarzeń - wzmacniają jego podmiotowośćc ${ }^{4}$. Obok małych narracji istnieją jeszcze „wielkie narracje”, będące - jak zauważa Straś-Romanowska ,tekstami kultury [...], których głównym celem jest usensownianie obrazu świata" 35 . Owe teksty kultury przybierają różną formę, bywają zbiorami praw, sposobów zachowań, podaniami, mitami, historiami ${ }^{36}$. Za wielką narrację można uznać „,każdą ogólną, sensotwórczą interpretację rzeczywistości i każdy system wiedzy - poglądowej, naukowej, artystycznej, ideologicznej, mający system paradygmatu i będący kluczem do rozumienia rzeczywistości" Wielkie narracje odnoszą się do zjawisk globalnych, społecznych, ważnych dla danej grupy lub też całego świata. Są wielkie, bo odnoszą się do fundamentalnych wartości i egzystencjalnych pytań, dotyczących życia, śmierci, przemijania, cierpienia itp. Wielkie narracje, którymi są np. mity czy podania, wpisują jednostkę ludzką we wspólnotę i ukazują sens życia społecznego, bycia wśród innych, relacji z innymi przedstawicielami tejże wspólnoty. Człowiek jest istotą rozdartą życiowo, pomiędzy byciem cześcią tej wspólnoty, przestrzeganiem jej systemu wartości, pomiędzy chęcią bycia w dialogicznej relacji z innymi ludźmi a poczuciem indywidualizmu, potrzebą realizacji własnych pragnień i podkreślania swojej odrębności ${ }^{38}$.

Teoria małych i wielkich narracji ma swoje odniesienie także w dokumencie radiowym. W myśl przedstawionych wyżej rozważań, reportażom audialnym można przypisać miano wielkich narracji, są przecież tekstami kultury, których autorzy starają się ukazać wartość prawd uniwersalnych, nadać otaczającym zjawiskom

\footnotetext{
33 Tamże, s. 21.

34 Zob. tamże, s. 24.

35 Tamże.

36 Zob. tamże.

37 Tamże, s. 25.

38 Zob. tamże, s. 33-35.
} 
głębszy sens. Reportażyści radiowi - poprzez swoją pracę - poszukują odpowiedzi na egzystencjalne pytania i starają się uwrażliwić odbiorców na ludzką krzywdę i cierpienie, a tym samym uzmysłowić człowiekowi wartość bycia w relacji z innymi, we wspólnocie. Dobry dokument radiowy - jak podkreślają zarówno praktycy, jak i teoretycy gatunku - poprzez indywidualną historię ukazuje wartości uniwersalne $^{39}$, sprawiając, że w mikrokosmosie odbija się makrokosmos. Irena Piłatowska zauważa, że reportażysta z mikrokosmosu danej sytuacji czy przeżyć konkretnego bohatera wydobywa makrokosmos - ,z powierzchni zdarzeń sięga do ich głębi’"મ0 - rzeczom jednostkowym nadając walor ponadczasowości. Tekst audialny więc, jak wielka narracja, „wyposaża egzystencję człowieka w wymiar ponadczasowy”41. Psychologia narracyjna mówi o tym, że wielkie narracje odbijają się w małych narracjach, ponieważ człowiek poszukuje fundamentalnych wartości w swoim życiu. Tak więc istnienie jednych narracji zależy od istnienia drugich ${ }^{42}$. Analizując reportaż radiowy jako tekst kultury w oparciu o teorię małych i wielkich narracji, można stwierdzić, że owe formy narracyjne nieustannie przeplatają się w dziele radiowym. Reportaż w rozumieniu wielkiej narracji powstaje w oparciu o małe narracje - opowieści bohaterów. $Z$ kolei ten sam tekst audialny staje się dla słuchacza pretekstem do poszukiwania uniwersalnych wartości w swoim życiu. Schemat narracji, małych i wielkich, w reportażu radiowym rysuje się w sposób następujący:

Rysunek 1. Wielkie i małe narracje a reportaż radiowy

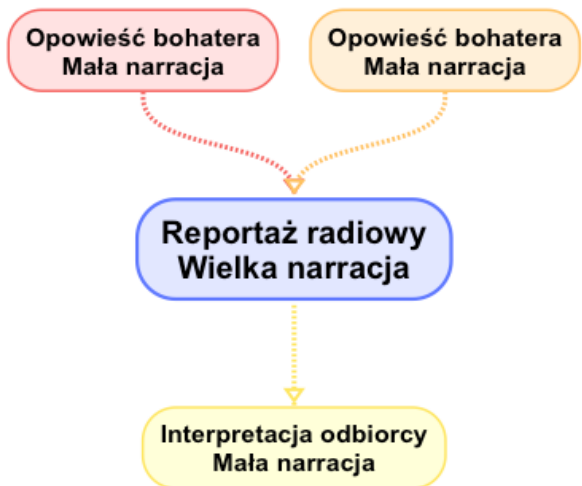

Źródło: oprac. własne.

${ }^{39}$ K. Michalak, wybitna polska reportażystka, w rozmowie z autorką tekstu, zwaraca uwagę na ten aspekt, mówiąc: „Zawsze chciałam opowiadać o świecie, ale najbardziej o ludziach. Wydobywać prawdy uniwersalne z indywidualnych historii".

${ }^{40}$ I. Piłatowska, Reportaż jako artystyczny gatunek radiowy, „Media - Społeczeństwo - Kultura" 2009, nr 1 (2), s. 34.

${ }^{41}$ M. Straś-Romanowska, dz. cyt., s. 26.

${ }^{42}$ B. Janusz, K. Gdowska, B. de Barbaro, dz. cyt., s. 7. 
Paralela między psychologią narracyjną a badaniami nad tekstami audialnymi rysuje się także, kiedy mowa o interpretacji wielkich narracji. Jak zauważa Straś-Romanowska: „wielkie narracje nie formułują gotowych sensów i nie zawsze są odczytywane dosłownie, w sposób jednoznaczny. Zawarte w nich przesłania mogą być interpretowane wielorako [...]"43. I w tym tkwi ich siła, w budzeniu wątpliwości, w prowokowaniu głębszej refleksji, w inspirowaniu do zadawania pytań. Podobnie reportaż radiowy - winien poruszać emocje słuchacza i wywoływać niepokój umysłu, a tym samym pobudzać proces interpretacji zjawisk. A analiza ich i interpretacja leżą przecież, jak pisałam wyżej, u podstaw procesu rozumienia. Są więc istotą człowieczeństwa.

\section{Specyfika przekazu radiowego}

Według Stownika terminów literackich „narracja jest wypowiedzią monologową przedstawiającą uporządkowany czasowo ciąg zdarzeń. Narracja jest podstawową jednostką wypowiedzi w utworze epickim. Jej rozwój wyznacza kształtowanie się świata przedstawionego, fabuły, postaci, tła zdarzeń [...]"44. O narracji mówi się więc w kontekście rozważań nad tekstem, a więc wypowiedzi powstałej w ramach konkretnego systemu znaków, pisanych, dźwiękowych, wizualnych, itp., „stanowiącej zamkniętą całość i skończoną całość z punktu widzenia treściowego" ${ }^{\$ 4}$. Reportaż radiowy jest tekstem, tekstem audialnym ${ }^{46}$, a więc wypowiedzią zapisaną w systemie znaków dźwiękowych. Tekst taki składa się z narracji werbalnych, a więc - jak zauważa Lobomir Dolezel - złożonych struktur tekstowych, których postawową cechą jest spójność fabuły. Badacz dodaje jednak, że

niektóre teksty narracyjne nie wykazują spójnej dominanty fabuły [...], inne zaś w ogóle nie tworzą żadnej fabuły spójnej [...], jednakże wszystkie poboczne struktury narracyjne można w pełni wyjaśnić tylko wtedy, gdy rozumie się strukturę typowego tekstu narracyjnego [tj. tekstu z dominującą fabułą $]^{47}$.

${ }^{43}$ M. Straś-Romanowska, dz. cyt., s. 33.

${ }^{44}$ J. Sławiński, Narracja, [w:] M. Głowiński i in., Stownik terminów literackich, red. J. Sławiński, Zakład Narodowy im. Ossolińskich, Wrocław 1988, s. 303-304.

${ }^{45}$ T. Kostkiewiczowa, Tekst, [w:] M. Głowiński i in., Słownik terminów..., s. 528.

${ }^{46}$ Termin ten wprowadzony został przez Elżbietą Pleszkun-Olejniczakową. Uważa ona słusznie, że reportaż radiowy [i słuchowisko], stanowią swoisty tekst kultury. Takie rozumienie reportażu radiowego ułatwia postrzeganie go na szerokim tle dokonań ogólnokulturowych, a nie tylko w perspektywie dzieł radiowych. E. Pleszkun-Olejniczakowa, K. Klimczak, Świat emocji reportaży radiowych Ireny Piłatowskiej, Anny Sekudewicz i Janiny Jankowskiej, [w:] Wyrażanie emocji, red. K. Michalewski, Wydawnictwo Uniwersytetu Łódzkiego, Łódź 2006, s. 318.

${ }^{47}$ L. Dolezel, Semantyka narracji, przekł. M.B. Fedewicz, [w:] Narratologia..., s. 124-125. 
Tekst audialny, nawet jeśli zawiera małe narracje o charakterze fragmentarycznym, niespójne fabularnie, to jako tekst audialny o strukturze wielkiej narracji winien być przekazem spójnym, którego kompozycja jest przemyślana, podporządkowana myśli dramturgicznej autora ${ }^{48}$.

Aby pełniej rozpoznać i zrozumieć rolę narracji w reportażu radiowym, przyjrzyjmy się krótko specyfice przekazu mówionego, a więc także słowu mówionemu, które jest - obok całej warstwy akustycznej - istotą narracji radiowej.

„Człowiek jest rzeczywiście, tak jak powiedział Arystoteteles, istotą mówiącą” - przyznaje rację autorowi Poetyki Hans-Georg Gadamer - „albowiem wszystko, co ludzkie, powinniśmy dać sobie powiedzieć" ${ }^{\prime 49}$. Z kolejnej perspektywy naukowej, teoretycznoliterackich rozważań o istocie języka, znajdujemy potwierdzenie potrzeby i naturalności werbalnych narracji. Wilhelm von Humboldt podkreśla znaczenie warstwy brzmieniowej znaków językowych. Werbalizowanie abstrakcyjnych myśli to nadawanie im konkretnej formy uchwytnej dla zmysłów:

Nierozerwalny związek myśli, narzędzi głosowych i organu słuchu z językiem leży niezmiennie w pierwotnym, nie dającym się dokładnie wyjaśnić ukonstytuowaniu ludzkiej natury [...]. Wyrazistość dźwięku mowy jest potrzebna umysłowi przy ujmowaniu przedmiotów ${ }^{50}$.

Narracja reportażu radiowego realizuje się w dźwięku, rozumianym jako - przede wszystkim - słowo mówione, ale również cała paleta dźwięków akustycznych i muzyki, dopełniających przekaz werbalny. Jaka jest natura tego dźwięku, a tym samym i narracji werbalnej? Dźwięk jest przede wszystkim towarzyszem - jak to określa Humboldt - ludzkich bóli, radości, lęków, jest

${ }^{48} \mathrm{O}$ cechach dobrego reportażu radiowego opowiedziała autorce wybitna reportażystka radiowa Janina Jankowska podczas Seminarium Reportażu poświęconego prezentacji i dyskusji warsztatowej nad radiowym dokumentem artystycznym, Kazimierz Dolny, dn. 29.10.2008 r. Jankowska zauważa, że reportaż powinien być zbudowany w oparciu o wyraźną linię dramaturgiczną: „Dobry reportaż to taki, od którego się nie oderwiemy [...], który zostawia ślady w naszym myśleniu [...], a nawet może zmienić nasze życie. Dobry reportaż od strony warsztatowej to taki, który ma napięcie, linię dramaturgiczną, który nam pokazuje bohatera intrygującego, ciekawego, innego, a jeśli nawet jest to bohater zwyczajny, codzienny, to odkrywa [reportażysta] w nim coś wyjątkowego, bo w codzienności też są rzeczy wyjątkowe. Słowem, dobry reportaż musi otworzyć okno, drzwi, otworzyć jakąś przestrzeń, w którą chcemy się [my-słuchacze] zanurzyć, w której się dobrze czujemy".

${ }^{49}$ H.G. Gadamer, Człowiek i język, [w:] Rozum, stowo, dzieje. Szkice wybrane, przekł. M. Łukasiewicz, K. Michalski, red. K. Michalski, Państwowy Instytut Wydawniczy, Warszawa 1979, s. 56.

${ }^{50}$ W. von Humboldt, Natura i właściwości języka, [w:] B. Andrzejewski, Wilhelm von Humboldt, przekł. B. Andrzejewski, Wiedza Powszechna, Warszawa 1989, s. 275-276. 
więc silnie związny w emocjonalnością człowieka ${ }^{51}$. A uczucia te [ekspresja] rozgrywają się w czasie, mają związek z konkretnymi momentami w życiu ${ }^{52}$. Dźwięk, a szczególnie wypowiedź oralna, jest dynamiczny, po pierwsze bowiem wybrzmiewa zawsze z użyciem jakiejś siły, ponadto wiąże się z ludzkim dzialaniem osadzonym $\mathrm{w}$ danym momencie czasowym ${ }^{53}$. Mowa ma charakter dialogiczny. Trudno bowiem, jak zauważa Ong - „godzinami mówić do siebie. Podtrzymywanie myśli wiąże się w kulturze oralnej z komunikowaniem” ${ }^{4}$. „Mówić - to mówić do kogos'"55 - zauważa z kolei Gadamer i dodaje, że słowo ma na celu nie tylko przedstawianie danego desygnatu, ale ukazanie tego przedmiotu temu, do którego się mówi. W tekście pisanym słowa są samotne, w przekazie mówionym istnieją zawsze $\mathrm{w}$ kontekście innych słów ${ }^{56}$. Zasada dialogicznej relacji dotyczy także struktur słownych, a więc wypowiedzi, które nasycone są odgłosami dialogu i tworzą się w procesie oddziaływania na siebie ${ }^{57}$. Pojedyncze osobiste narracje, składające się na wielką narrację przekazu audialnego, pozostają wobec siebie w relacji, w ciągłym dialogu, „są siebie świadome i nawzajem odzwierciedlają się w sobie" 58 - parafrazując słowa Michaiła Bachtina - pełne są ech i pogłosów innych narracji i ich rekonfiguracji.

Tekst audialny, powstały jako multiplikacja małych narracji o różnym brzmieniowym charakterze, ma swoją autonomię, jest otwarty na wielość odczytań i interprtacji ${ }^{59}$. Każdy słuchacz, wyposażony w bagaż doświadczeń i związanych z nimi emocji, interpretuje dzieło przez ich pryzmat. Co więcej, odczytanie to może ewoluować wraz ze zmieniającymi się doświadczeniami i przeżyciami odbiorcy. „Ta możliwość wielokrotnych odczytań stanowi dialektyczny odpowiednik semantycznej autonomii tekstu" ${ }^{\prime 60}$. Także reportażu radiowego jako tekstu kultury.

Wyposażeni w wiedzę narratologiczną z zakresu teorii literatury, psychologii, filozofii oraz komunikologii i świadomi przekładalności spostrzeżeń tych nauk na rozważania o tekście audialnym, przyjrzyjmy się typom narracji w reportażu radiowym.

\footnotetext{
${ }^{51}$ Zob. tamże.

52 Zob. W.J. Ong, Psychodynamika oralności, przekł. J. Japola, [w:] Antropologia ..., s. 191-192.

53 Zob. tamże, s. 192.

54 Tamże, s. 193.

55 H.G. Gadamer, dz. cyt., s. 55.

56 Zob. W.J. Ong, Pismo a struktura świadomości, przekł. M. Pęczak, [w:] Antropologia..., s. 377.

${ }^{57}$ M. Bachtin, Słowo dialogu-dialogowość słowa, przekł. D. Ulicka, [w:] Antropologia ..., s. 161.

58 Tamże, s. 160.

${ }^{59}$ P. Ricoeur, Mowa i pismo, przekł. K. Rosner, [w:] Antropologia..., s. 426.

60 Tamże.
} 


\section{Narracja w reportażu radiowym}

Wedle poczynionych wyżej rozważań uzasadnione jest patrzenie na dzieło audialne jako formę wielkiej narracji. Ten rodzaj tekstu kultury, zrealizowny w systemie znaków dźwiękowych, składa się z wielu typów mniejszych narracji, które łączą się ze sobą strukturalnie i semantycznie, uzupełniają swoją wartość znaczniową, wzmacniają nawzajem swoje sensy, słowem - ich kompozycja w całości przekazu jest przemyślana, zgodna z zasadmi budowania dramaturgii tekstu, tu audialnego.

Ogólna struktura typów narracji w reportażu radiowym rysuje się - moim zdaniem - jak poniżej:

Rysunek 2. Narracja w reportażu radiowym

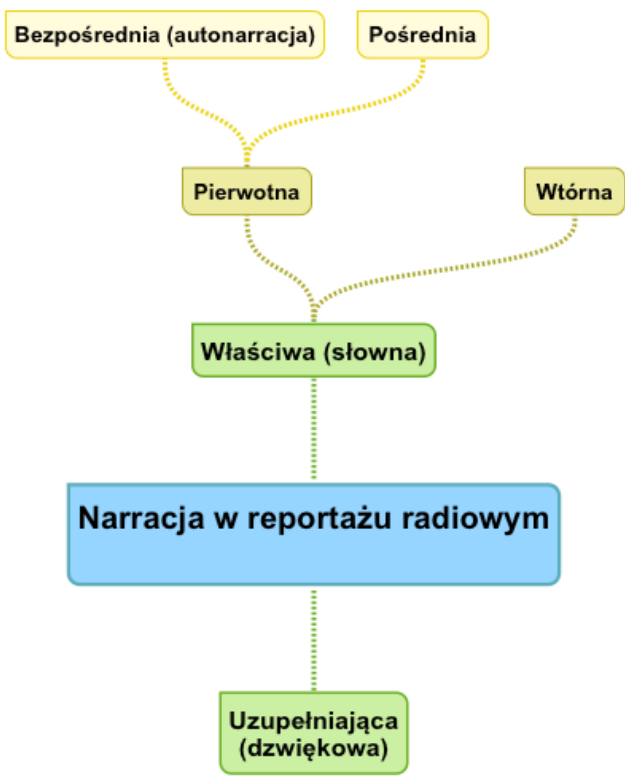

Źródło: oprac. własne.

Fabuła reportażu radiowego oparta jest na małych narracjach słownych, a więc opowieściach bohaterów lub werbalnych przekazach. Bywają reportaże składające się z narracji tylko jednego bohatera. Zdarza się, że jeden głos jest dominujący, a prezentowana przezeń opowieść stanowi główną oś fabularną, uzupełnioną o pomniejsze narracje innych bohaterów. Są też teksty audialne, w których mamy do czynienia z bohaterem zbiorowym - wówczas waga wszystkich głosów składających się na wielką narrację jest taka sama lub podobna. Można mówić o wielości sposobów artykułowania narracji słownych w dziele audialnym - każdy reportaż należy pod tym względem rozpatrywać indywidualnie. 
Określiłam narracje słowne jako właściwe dla reportażu radiowego, gdyż stanowią one w większości podstawową warstwę narracyjną takiego przekazu. Wyjątkiem są dzieła audialne oparte tylko na dźwiękach akustycznych i muzyce - czego przykładem są eksperymentalne prace Eugeniusza Rudnika ${ }^{61}$. Słowo jest jednak wciąż prymarnym tworzywem audialnej opowieści. Jak zauważa Katarzyna Rosner, narrację cechuje czasowość i skończonośćc ${ }^{2}$, a takich cech możemy doszukiwać się $\mathrm{w}$ werbalnych przekazach bohaterów reportażu radiowego. Semantyka przekazu narracji słownych wspomagana jest poprzez narracje uzupełniające, mające dźwiękowy charakter. Mogą być nimi różne środki audialnego tworzywa, takie jak efekty aktustyczne, muzyka czy cisza, będąca swoistym rodzajem dźwięku, a konkretnie jego brakiem. Takie narracje mają najcześciej charakter fragmentaryczny, wzmacniają treści przekazów słownych, uzupełniają ich sens, stanowią dla nich kontrapunkt, budują nastrój itp. Do uznania tych elementów dźwiękowych za rodzaj narracji uprawniają nas po pierwsze cytowane wyżej słowa Barthesa o konstruowaniu narracji w każdym systemie znakowym ${ }^{63}$; po drugie rodzaj tworzywa tekstu, o jakim mowa, jego audialność.

Słowne, właściwe narracje może podzielić na pierwotne i wtórne, co odnosi się do sposobu ich istnienia w tekście audialnym. Narracje pierwotne [audialnie] to takie, których prymarne istnienie jest dźwiękowe, to znaczy, że od początku funkcjonowały jako przekaz audialny. W tej kategorii znajdują się wypowiedzi różnych bohaterów reportażu, ekspresywne opowieści, werbalizowane w trakcie rozmowy z reportażystą. Za narracje wtórne [audialnie] uznaję te partie narracyjne reportażu, których pierwotny byt jest pisany, a którym foniczny wymiar został nadany z chwilą włączenia ich w przekaz radiowy, audialny. Umieścić tu należy wszelkie fragmenty tekstów pisanych, takich jak książki, pamiętniki, dokumenty, ale także narrację odautorską czy fragmenty czytane przez lektora. Wszystkie one, po nadaniu im audialnej formy istnienia, stanowią ważny element narracyjny radiowego reportażu. Bardzo często to właśnie narracje wtórne audialnie stanowią podstawowe źródło wiedzy o bohaterze audycji. Dzieje się tak np. kiedy bohater w czasie tworzenia reportażu nie żyje, ale pozostawił po sobie listy, pamiętnik lub opublikowaną książkę. Wówczas zapisane przez niego teksty stają się częścią reportażu poprzez odczytanie ich przez aktora. Bohater odżywa, daje siebie poznać, ale już nie w bezpośredniej formie. Tekst przekazu należy do niego - słowa, struktury zdań - ale interpretacja tekstu już nie.

${ }^{61}$ B. Błaszczyk, Wstęp do albumu Eugeniusz Rudnik. Studio Eksperymentalne Polskiego Radia, Radiowa Agencja Fonograficzna, Warszawa 2008.

${ }^{62}$ Zob. K. Rosner, Narracja, tożsamość i czas, Towarzystwo Autorów i Wydawców Prac Naukowych Universitas, Kraków 2003, s. 7.

${ }^{63},[\ldots]$ opowiadania pojawiają się zarówno w języku artykułowanym, mówionym lub pisanym, jak i w obrazie statycznym lub ruchomym geście [...]”. R. Barthes, dz. cyt., s. 327. 
Narrację pierwotną możemy podzielić na bezpośrednią i pośrednią. Narracje bezpośrednie to opowieści bohatera o sobie samym, a więc autonarracje, bowiem jak zauważa Trzebiński: „gdy narracje dotyczą własnej osoby, to znaczy gdy tworzący narrację podmiot jest ich pierwszoplanowym bohaterem, mówimy o autonarracjach"64. Autonarracja leży u podstaw budowania tożsamości narracyjnej bohatera:

Treść rozwijającej się autonarracji determinuje zachowania jednostki. Jednostka w swej autonarracji jest bowiem głównym lub jednym z głównych bohaterów dziejącej się historii, a więc jej rozumienie siebie, w swojej sytuacji, w tym także rozumienie własnych motywów, emocji, decyzji oraz działań i ich efektów są wkomponowane w treść opowieści ${ }^{65}$.

Konsekwencją tego faktu jest proces budowania tożsamości narracyjnej.

Narracja bezpośrednia to zapis autentycznej wypowiedzi bohatera, który pozwala nam poznać go najbliżej i w najczystszej formie. Możemy bezpośrednio poczuć jego emocje, posłuchać barwy jego głosu, zobaczyć, w jaki sposób konstruuje zdania, jakie dobiera słowa. W narracji bezpośredniej jesteśmy najbliżej bohatera, szczególnie, że opowiada on o sobie samym, przeżywa własną opowieść, jest jej bohaterem.

Jednak bohatera i jego historię możemy poznać pośrednio, poprzez trzecioosobową narrację innego bohatera. I choć treść przekazu nie dotyczy bezpośrednio nadawcy, to forma narracji na pewno tak. Sposób opowiadania zdradza stany uczuciowe opowiadającego, a tym samym jego stosunek do podmiotu / przedmiotu opowieści - negatywny, pozytywny lub neutralny.

Zatrzymajmy się chwilę na narracjach pierwotnych dźwiękowo, a więc na wypowiedziach bohaterów tekstu audialnego. Poprzez te narracje - o sobie samym czy o innych osobach, bezpośrednie czy pośrednie - możemy poznać bohaterów na wielu płaszczyznach opowieści - zarówno w warstwie językowej, jak i prozodycznej. Jak pisze Edward Sapir: ,podstawowe cechy głosu, fonetyka, wymowa, szybkość i płynność artykulacji, długość i budowa zdań - wszystko to są skomplikowane wskaźniki osobowości mówiącego" ${ }^{\prime 6}$. Poniższy rysunek ilustruje, jakie elementy strukturalne składają się na narrację bohatera, a tym samym charakteryzują go, zdradzają jego emocje, stan wiedzy, wiek, temperament, pochodzenie $\mathrm{i}$ in.

${ }^{64}$ J. Trzebiński, Narracyjne konstruowanie rzeczywistości, [w:] Narracja jako sposób..., s. 36.

${ }^{65}$ Tamże, s. 36-37.

${ }^{66}$ E. Sapir, Mowa jako rys osobowości, [w:] tenże, Kultura, język, osobowość. Wybrane eseje, przekł. B. Stanosz, R. Zimand, wstęp A. Wierzbicka, Państwowy Instytut Wydawniczy, Warszawa 1978, s. 74. 
Rysunek 3. Narracja pierwotna

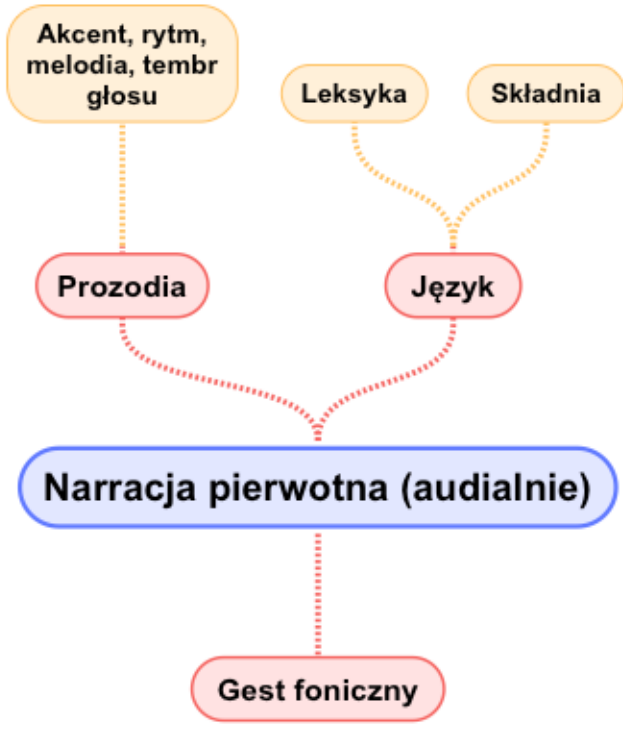

Źródło: oprac. własne.

Na portret bohatera składa się zarówno prozodyczna, jak i językowa warstwa wypowiedzi. Z jednej strony rozłożenie akcentów, melodia i rytm wywodu, jego intonacja, a także tembr głosu, z drugiej dobór leksyki, a dalej sposób konstruowania słów w zdania - wszystkie te elementy znaczą, wpływają na obraz bohatera, jaki kształtuje się w umyśle odbiorcy. Komponentem dopełniającym ten audialny portret są gesty foniczne, określane także jako „dźwiękowe ruchy mimiczne"67, ponieważ są fonicznymi korelatami reakcji bohatera towarzyszącymi procesowi mówienia. Jak zauważa Józef Mayen: „gest foniczny potrafi nie tylko [...] zastąpić słowo czy wyjaśnić zdanie, lecz staje się czasem ekwiwalentem całego zdania, staje się samoistnym powiadomieniem"68. Co więcej, gest foniczny - będący np. wykrzyknikiem, dźwiękiem onomatopeicznym, gestem śródsłownym - jest, moim zdaniem, oznaką dialogu, jaki towarzyszy procesowi mówienia, werbalizowania własnych przeżyć; świadczy o przeżywaniu przez bohatera swojej opowieści, o snuciu nad nią refleksji, słowem jest dowodem na to, że narracja pozwala na kształtowanie własnej tożsamości.

${ }^{67}$ Cyt. za: J. Mayen, O stylistyce utworów mówionych, Zakład Narodowy im. Ossolińskich, Wrocław 1972, s. 97.

68 Tamże. 


\section{Zakończenie}

Zamieszczone wyżej propozycje podziału warstwy narracyjnej reportażu radiowego noszą znamiona skrótowości i są punktem wyjścia do dalszych rozważań. Każdy tekst audialny należy bowiem rozpatrywać indywidualnie. Istnieją z pewnością takie, które wykraczają poza ramy zaproponowanego przeze mnie podziału. Wynika to choćby z poetyki czasów konwergencji. Przenikają się nie tylko cechy mediów, ale także gatunków w obrębie mediów. Co więcej, zmienność, dynamika, ruch - co podkreślałam wyżej - jest cechą przekazów oralnych. Dlatego perspektywa pośrednia narracji może w tym samym tekście audialnym przekształcić się w bezpośrednią, stać się autonarracją. W strukturze tekstu audialnego narracje mogą być rozczłonkowanie innymi narracjami, słownymi lub dźwiękowymi. To rozczłonokowanie małych narracji ma znaczenie dla sensu przekazu wielkiej narracji. Wielka narracja, tekst audialny, jest opowieścią przemyślaną, w strukturze której kolejne elementy tworzywa podporządkowane są wizji autora.

Powyższe rozważania dowodzą, że dzieło audialne nie powinno być pomijane w badaniach narratologicznych. Narracje są bowiem obecne wszędzie, jak zauważa Anna Burzyńska - powołując się na słowa Jeana Françoisa Lyotarda - „tworzą się w kategoriach swoich własnych pragmatyk, jako skomplikowany i zmienny zbiór stosunków pomiędzy narratorem a narracją, narratorem a słuchaczem, słuchaczem a opowieścią prezentowaną przez narratora"69. Te narracyjne zależności są obecne także w reportażu radiowym.

\section{Bibliografia}

Bachtin M., Słowo dialogu - dialogowość słowa, przekł. D. Ulicka, [w:] Antropologia słowa. Zagadnienia i wybór tekstów, red. G. Godlewski, Wydawnictwa Uniwersytetu Warszawskiego, Warszawa 2003, s. 160-164.

Barthes R., Wstęp do analizy strukturalnej opowiadań, przekł. W. Błońska, „Pamiętnik Literacki” 1986, z. 4, s. 327-359.

Błaszczyk B., Wstęp do albumu Eugeniusz Rudnik. Studio Eksperymentalne Polskiego Radia, Radiowa Agencja Fonograficzna, Warszawa 2008.

Bok B., Encounter with the Other. Some reflections on interviewing, Stockholm Academy of Dramatic Arts, Stockholm 2014.

Burzyńska A., Idee narracyjności w humanistyce, [w:] Narracja. Teoria i praktyka, red. B. Janusz, K. Gdowska, B. de Barbaro, Wydawnictwo Uniwersytetu Jagiellońskiego, Kraków 2008, s. 21-36.

Czyżowska D., Dylematy moralne osób dorostych i sposoby ich rozwiązywania, [w:] Psychologia matych $i$ wielkich narracji, red. M. Straś-Romanowska, B. Bartosz, M. Żurko, Eneteia. Wydawnictwo Psychologii i Kultury, Warszawa 2010, s. 41-58.

${ }^{69}$ A. Burzyńska, Idee narracyjności w humanistyce, [w:] Narracja. Teoria..., s. 26-27. 
Dolezel L., Semantyka narracji, przekł. M.B. Fedewicz, [w:] Narratologia, red. M. Głowiński, Wydawnictwo Słowo/Obraz Terytoria, Gdańsk 2004, s. 124-153.

Filar D., Narracyjność w badaniach interdyscyplinarnych a kategorie narracyjne w semantyce, [w:] Narracyjność języka i kultury, red. D. Filar, Wydawnictwo Uniwersytetu Marii Curie-Skłodowskiej, Lublin 2014, s. 13-33.

Gadamer H.G., Człowiek i język, [w:] Rozum, słowo, dzieje. Szkice wybrane, przekł. M. Łukasiewicz, K. Michalski, red. K. Michalski, Państwowy Instytut Wydawniczy, Warszawa 1979, s. $47-56$.

Głowiński M., Wokót narratologii, [w:] Narratologia, red. M. Głowiński, Wydawnictwo Słowo/ Obraz Terytoria, Gdańsk 2004.

Humboldt von W., Natura i właściwości języka, [w:] B. Andrzejewski, Wilhelm von Humboldt, przekł. B. Andrzejewski, Wiedza Powszechna, Warszawa 1989, s. 275-284.

Janusz B., Gdowska K., Barbaro B. de, Praktykowanie narracji, [w:] Narracja. Teoria i praktyka, red. B. Janusz, K. Gdowska, B. de Barbaro, Wydawnictwo Uniwersytetu Jagiellońskiego, Kraków 2008, s. 7-8.

Kłoczowski J.A. OP, Filozofia dialogu, Wydawnictwo Polskiej Prowincji Dominikanów „W drodze", Poznań 2005.

Kostkiewiczowa T., Tekst, [w:] M. Głowiński i in., Słownik terminów literackich, red. J. Sławiński, Zakład Narodowy im. Ossolińskich, Wrocław 1988, s. 528.

Mayen J., O stylistyce utworów mówionych, Zakład Narodowy im. Ossolińskich, Wrocław 1972.

Michalak K., wykład pt. Od pierwszego wejrzenia czyli moje sposoby przeprowadzania wywiadów wygłoszony podczas Seminarium Reportażu poświęconego prezentacji i dyskusji warsztatowej nad radiowym dokumentem artystycznym, Kazimierz Dolny, dn. 22.10.2007 [zarejestrowany wykład w posiadaniu autorki tekstu].

Narracja jako sposób rozumienia świata, red. J. Trzebiński, Gdańskie Wydawnictwo Psychologiczne, Sopot 2001.

Ong W.J., Pismo a struktura świadomości, przekł. M. Pęczak, [w:] Antropologia słowa. Zagadnienia $i$ wybór tekstów, red. G. Godlewski, Wydawnictwo Uniwersytetu Warszawskiego, Warszawa 2003, s. 368-380.

Ong W.J., Psychodynamika oralności, przekł. J. Japola, [w:] Antropologia słowa. Zagadnienia $i$ wybór tekstów, red. G. Godlewski, Wydawnictwa Uniwersytetu Warszawskiego, Warszawa 2003, s. 191-202.

Pawluczuk W., Zwierzenie, gawędzenie, zgryzota, [w:] Antropologia słowa. Zagadnienia i wybór tekstów, red. G. Godlewski, Wydawnictwa Uniwersytetu Warszawskiego, Warszawa 2003, s. $176-181$.

Piłatowska I., Reportaż jako artystyczny gatunek radiowy, „Media - Społeczeństwo - Kultura” 2009, nr 1 (2), s. 30-39.

Pleszkun-Olejniczakowa E., Klimczak K., Świat emocji reportaży radiowych Ireny Piłatowskiej, Anny Sekudewicz i Janiny Jankowskiej, [w:] Wyrażanie emocji, red. K. Michalewski, Wydawnictwo Uniwersytetu Łódzkiego, Łódź 2006, s. 317-326.

Ricoeur P., Filozofia osoby, przekł. M. Frankiewicz, Wydawnictwo Naukowe Papieskiej Akademii Teologicznej w Krakowie, Kraków 1992.

Ricoeur P., Mowa i pismo, przekł. K. Rosner, [w:] Antropologia słowa. Zagadnienia i wybór tekstów, red. G. Godlewski, Wydawnictwa Uniwersytetu Warszawskiego, Warszawa 2003, s. $423-429$. 
Rosner K., Narracja, tożsamość i czas, Towarzystwo Autorów i Wydawców Prac Naukowych Universitas, Kraków 2003.

Sapir E., Mowa jako rys osobowości, [w:] tenże, Kultura, język, osobowość. Wybrane eseje, przekł. B. Stanosz, R. Zimand, wstęp A. Wierzbicka, Państwowy Instytut Wydawniczy, Warszawa 1978, s. 69-84.

Sławiński J., Narracja, [w:] M. Głowiński i in., Słownik terminów literackich, red. J. Sławiński, Zakład Narodowy im. Ossolińskich, Wrocław 1988, s. 303-304.

Słownik języka polskiego, t. 2, red. H. Szkiłądź i in., Państwowe Wydawnictwo Naukowe, Warszawa 1979.

Straś-Romanowska M., Psychologia wobec matych $i$ wielkich narracji, [w:] Psychologia matych i wielkich narracji, red. M. Straś-Romanowska, B. Bartosz, M. Żurko, Eneteia. Wydawnictwo Psychologii i Kultury, Warszawa 2010, s. 21-40.

Teorie literatury XX wieku. Podręcznik, red. A. Burzyńska, M.P. Markowski, Społeczny Instytut Wydawniczy Znak, Kraków 2007.

Tischner J., Myślenie wedlug wartości, Społeczny Instytut Wydawniczy Znak, Kraków 2005.

Trzebiński J., Problematyka narracji we wspótczesnej psychologii, [w:] Narracja. Teoria i prakty$k a$, red. B. Janusz, K. Gdowska, B. de Barbaro, Wydawnictwo Uniwersytetu Jagiellońskiego, Kraków 2008, s. 9-17.

\section{Kinga Sygizman}

\section{Narrativity of radio documentary}

\section{(Summary)}

The author takes up the question of the narrativity of the artistic radio message that is radio documentary. It looks at documenatry from the perspective of psychological research on storytelling. Hence it considers the radio documentary as a large-scale narration composed of smaller aural forms, constituting small narrations. The author examines numerous levels of the in-depth news report, lexical, prosodic and also phonic features.

It also shows how the theory of radio documentary connects to narrative identity.

Keywords: narration, radio documentary, dialogue, story telling, identity. 